\title{
Behaviour and passage of European silver eels (Anguilla anguilla) at a small hydropower plant during their downstream migration
}

\author{
F. Travade ${ }^{(1)}$, M. Larinier ${ }^{(2)}$, S. Subra ${ }^{(1)}$, P. Gomes ${ }^{(2)}$, E. De-Oliveira ${ }^{(1)}$
}

Received May 3rd, 2010 / Reçu le 3 mai 2010

Revised July 6, 2010 / Révisé le 6 juillet 2010

Accepted July 6, 2010 / Accepté le 6 juillet 2010

Key-words:
silver eel,
downstream
migration,
behaviour,
hydroelectric
plant,
trashracks,
radio-tracking

\section{ABSTRACT}

\begin{abstract}
Between 2004 and 2007, 116 downstream migrant silver eels (Anguilla anguilla) were monitored at a hydropower plant on the Gave de Pau river in South-West France using radio and PIT telemetry. The objectives of the study were: (i) to determine the environmental conditions when eels arrived and passed the facility; (ii) to determine the rate of eel escapement (passage other than via the turbines); (iii) to describe the behaviour of eels faced with the intake structure and the permeability of the intake trashracks for the different sizes of eel; and (iv) to determine whether surface bypasses originally designed for salmon could be effective for eels. Five types of behaviour of silver eels in the forebay and at the plant intakes were identified. The study showed the key factor influencing both eel behaviour and the route taken through the plant was variation in river discharge. Escapement rate was related to eel length and the spill flow to river flow ratio, which could be described by a logistic regression model. The surface bypasses originally designed for salmon were found to aid downstream eel migration significantly. At velocities $<0.40 \mathrm{~m} \cdot \mathrm{s}^{-1}$, no eels, even the largest, for which the racks are a physical barrier, were found impinged on the trashracks.
\end{abstract}

\section{RÉSUMÉ}

Comportement et passage de l'anguille argentée (Anguilla anguilla) au niveau d'une petite centrale hydroélectrique lors de sa migration de dévalaison

Mots-clés : anguille argentée, migration de dévalaison, comportement, centrale hydroélectrique, grilles, radio-télémétrie
De 2004 à 2007, une étude sur la migration de dévalaison de l'anguille argentée européenne (Anguilla anguilla) a été menée sur la centrale hydroélectrique de Baigts sur le Gave de Pau dans le Sud-Ouest de la France. Cette étude, au cours de laquelle 116 individus ont été suivis par télémétrie PIT et radio, avait pour objectifs : (i) de déterminer les conditions de milieu propices à l'arrivée sur site et au franchissement de l'aménagement; (ii) de déterminer les taux d'échappement (passages par des voies autres que les turbines); (iii) d'analyser le comportement des anguilles devant les ouvrages et la perméabilité des grilles de la prise d'eau en fonction de la taille des individus; (iv) de tester la fonctionnalité, pour l'anguille, d'exutoires de surface initialement prévus pour le saumon. Cinq types

(1) Électricité de France, Research and Development, 6 quai Watier, 78400 Chatou, France

(2) French National Office for Water \& Aquatic Environments (Office National de l'Eau et des Milieux Aquatiques ONEMA), Pôle Écohydraulique, Institut de Mécanique des Fluides de Toulouse, Allée du Professeur Camille Soula, 31400 Toulouse, France, michel.larinier@imft.fr 
de comportement de l'anguille argentée ont été identifiés. L'étude fait apparaître que le débit du cours d'eau et ses variations jouent un rôle majeur, tant sur le comportement des anguilles que sur les voies de franchissement (turbines, évacuateurs de crue ou exutoire). Le taux d'échappement a pu être modélisé en fonction de la taille des anguilles et de la répartition des débits entre les ouvrages évacuateurs et les turbines par une régression logistique. L'apport des exutoires de surface conçus à l'origine pour le saumon s'avère significatif pour la dévalaison de l'anguille. Pour des vitesses d'approche $<0,40 \mathrm{~m} \cdot \mathrm{s}^{-1}$, aucun placage d'anguilles n'a été enregistré aux grilles, même sur les plus gros individus pour qui les grilles constituent une barrière physique.

\section{INTRODUCTION}

The requirements relating to the safe passage of the European silver eel (Anguilla anguilla) through barriers such as hydros are currently increasing, because the eel population has been in dramatic decline in France and the rest of Europe for a number of years. European Council Regulation no. 1100/2007 establishes measures for the recovery of European eel stocks that include the requirement for all member states to reduce the anthropogenic mortality factors. Damage to downstream migrant silver eel passing through turbines at hydroelectric facilities can be high and is mostly due to mechanically-caused injuries because of their elongated morphology (Monten, 1985; EPRI, 2001; Larinier and Travade, 2002; Travade and Larinier, 2006). Various types of physical screening and also behavioural barriers based on light, sound and electricity have been tested, but none of them has proved both biologically effective and economically acceptable (Hadderingh and Baker, 1998; Hadderingh et al., 1999; Sand et al., 2000; EPRI, 2001; Amaral et al., 2003; Boubée and Williams, 2006). In order to develop effective technologies, particularly improvement in trashrack design criteria, we need to understand better the downstream migration of the eel and its behavioural response at hydroelectric water intakes.

Telemetry experiments (radio-tracking and PIT) were performed at Baigts powerplant, an $8 \mathrm{MW}$ hydroelectric facility operated by EDF located on the Gave de Pau river, during the silver eel migration period (from October to February) in 2004-2005, 2005-2006 and 2006-2007. These studies, respectively termed as the '2004', '2005' and '2006' studies, focused on the following questions:

- What are the environmental conditions when eels arrive at the facility?

- How do silver eels behave in the forebay and at the power intakes?

- What are the passage routes at the facility, and in particular what are the probabilities of escapement through the spillway?

- Are the downstream surface bypasses, originally designed for juvenile salmon, effective for silver eels?

\section{MATERIAL AND METHODS}

\section{> STUDY SITE}

The Baigts hydroelectric facility is located in the southwest of France, on the Gave de Pau river (Figure 1), $20 \mathrm{~km}$ above its confluence with the Gave d'Oloron river and approximately $50 \mathrm{~km}$ from the estuary. The mean annual daily flow is $85 \mathrm{~m}^{3} \cdot \mathrm{s}^{-1}$ : the mean monthly flow values vary from $30 \mathrm{~m}^{3} \cdot \mathrm{s}^{-1}$ in August and September, to over $100 \mathrm{~m}^{3} \cdot \mathrm{s}^{-1}$ in May-June, December and January.

The plant (Figure 2) comprises a dam and two powerhouses. The main powerhouse is located on the right bank, while a mini-plant, built in 2006 to provide additional attraction flow to the fish lift entrance, is located on the left bank. The dam is $57 \mathrm{~m}$ long and spill is controlled 


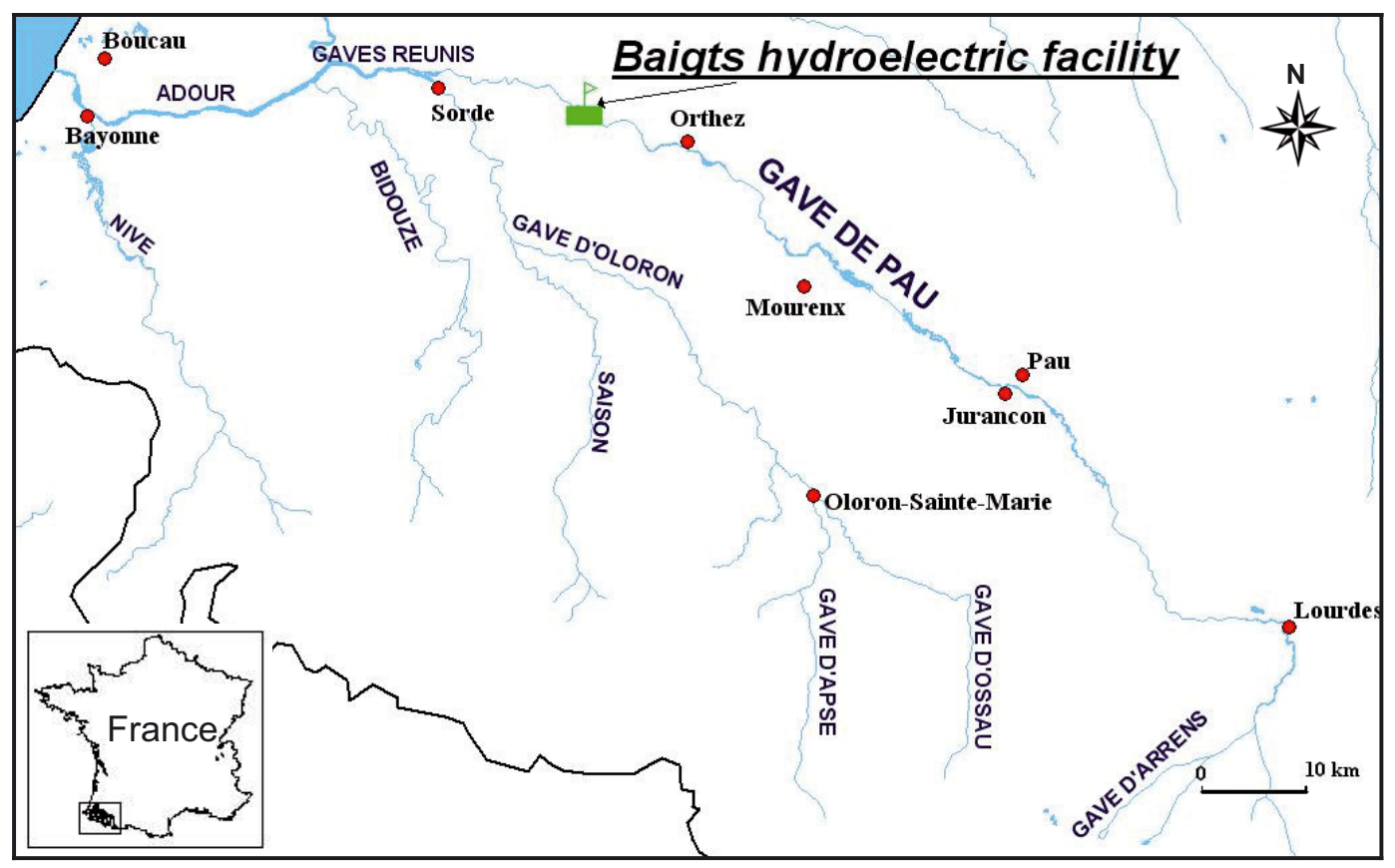

Figure 1

Location of the Baigts hydroelectric plant on the Gave de Pau river.

Localisation de l'aménagement hydroélectrique de Baigts sur le Gave de Pau.

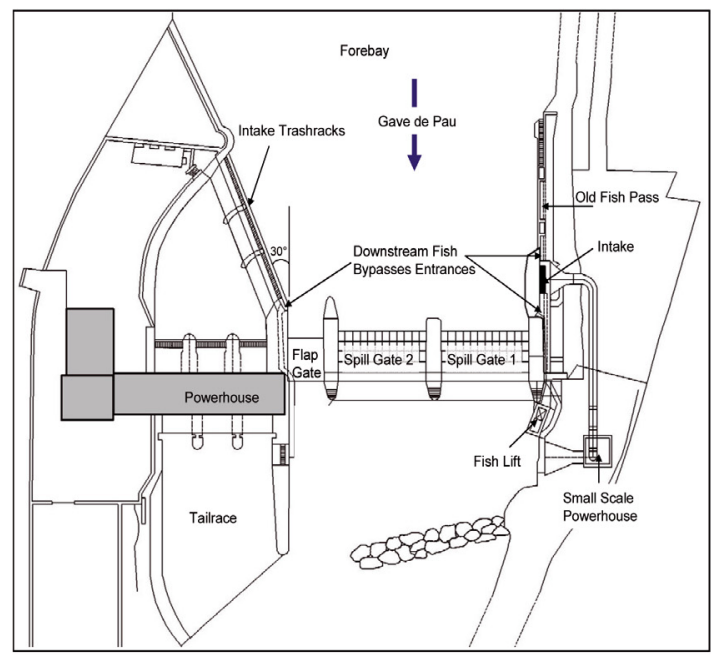

A

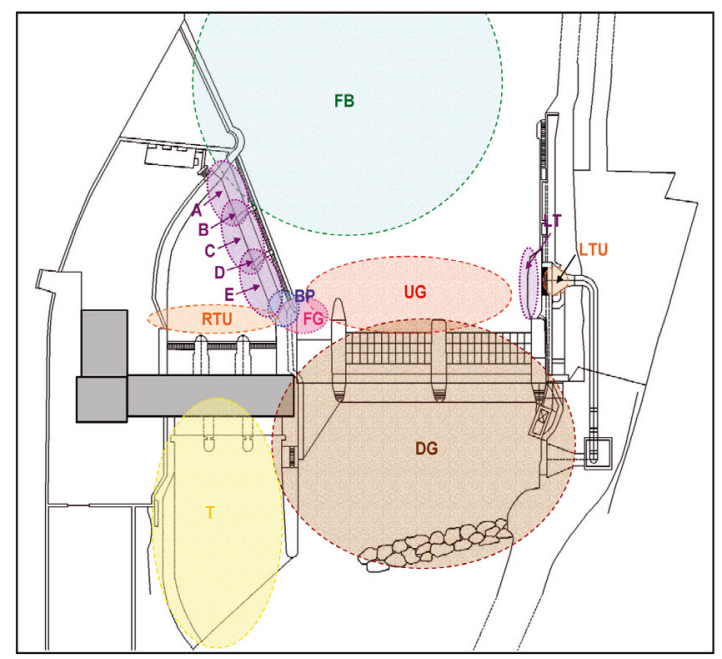

B

\section{Figure 2}

Schematic diagram of the Baigts hydroelectric facility and location of the radio-tracking recording zones. (FB: forebay, UG: upstream side of gates, FG: flap gate, BP: main bypass entrance, RTU: turbine entrance (main hydroplant), LT: trashrack (mini-plant), LTU: turbine entrance (mini-plant), DG: downstream side of gates, T: tailrace, $A$ to $E$ : recording zones along the main trashrack.)

\section{Figure 2}

Schéma de l'usine hydroélectrique de Baigts et localisation des zones d'enregistrement de radiopistage. (FB : retenue, UG : amont vannes, FG : clapet, BP : entrée exutoire, RTU : entrée turbines (usine principale) rive droite, LT : grille (mini-centrale), LTU : entrée turbine (mini-centrale), DG : aval vannes, $\mathrm{T}$ : canal de fuite, $\mathrm{A}$ à $\mathrm{E}$ : zones de réception le long de la grille de la prise d'eau principale.) 


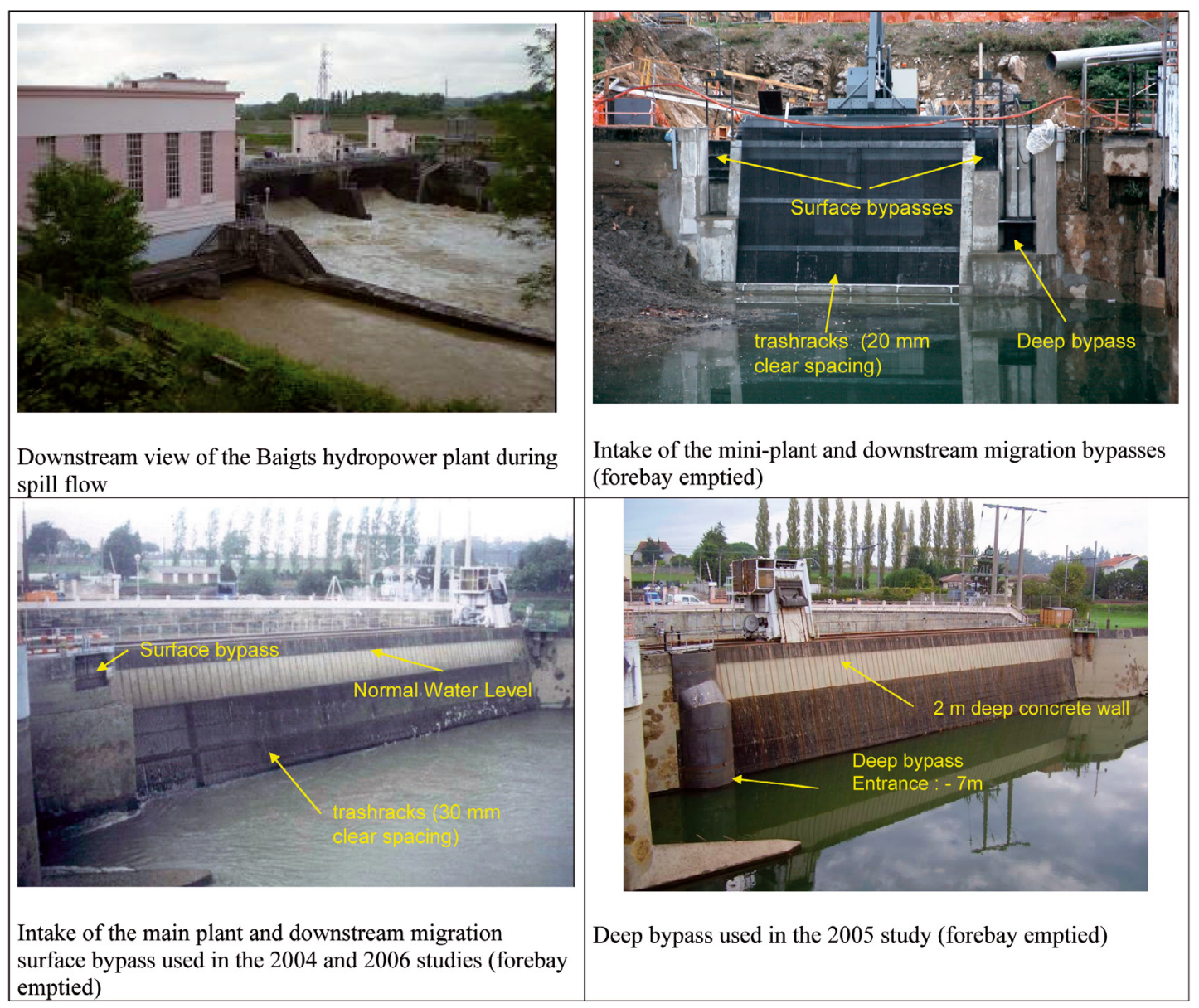

\section{Figure 3}

Views of the Baigts main intake plant and downstream migration bypasses for the main and mini-power plants.

Figure 3

Photos du site de Baigts et des exutoires de dévalaison sur l'usine principale et sur la mini-centrale.

by two radial gates $20 \mathrm{~m}$ wide together with a smaller flap gate $7.5 \mathrm{~m}$ wide mounted above a bottom slide gate adjacent to the main power intake.

At the entrance of the main intake, water flows through a trashrack, consisting of rectangular bars spaced $3 \mathrm{~cm}$ apart. The racks are $40.2 \mathrm{~m}$ long, $5 \mathrm{~m}$ deep and set at an angle of $30^{\circ}$ to the axis of the river. The maximum approach velocity of flow ${ }^{1}$ to the trashrack area is $0.44 \mathrm{~m} \cdot \mathrm{s}^{-1}$. The uppermost point of intake at the racks is located approximately $2 \mathrm{~m}$ below the water level in the impoundment. The bottom of the trashrack is approximately $5 \mathrm{~m}$ above the reservoir bed. The run-of-river generating station is equipped with three Kaplan turbine runners, each driven by $30 \mathrm{~m}^{3} \cdot \mathrm{s}^{-1}$ at full generating capacity with a net operating head of $9.60 \mathrm{~m}$.

The maximum turbine flow of the mini-power station (Figure 2) is around $12 \mathrm{~m}^{3} \cdot \mathrm{s}^{-1}$. The water intake has a trashrack $7.4 \mathrm{~m}$ long and $4.6 \mathrm{~m}$ high (surface area $34 \mathrm{~m}^{2}$ ) with rectangular bars spaced $20 \mathrm{~mm}$ apart. The trashrack extends from the top to the bottom of the water column (Figure 3). The maximum approach velocity of flow is $0.35 \mathrm{~m} \cdot \mathrm{s}^{-1}$. This power station ran only during the 2006 experiment and operated at reduced capacity $\left(7 \mathrm{~m}^{3} \cdot \mathrm{s}^{-1}\right)$, so that the approach velocity to the racks was limited to around $0.20 \mathrm{~m} \cdot \mathrm{s}^{-1}$.

${ }^{1}$ Maximum approach velocity = maximum plant intake flow rate divided by the screen area. 


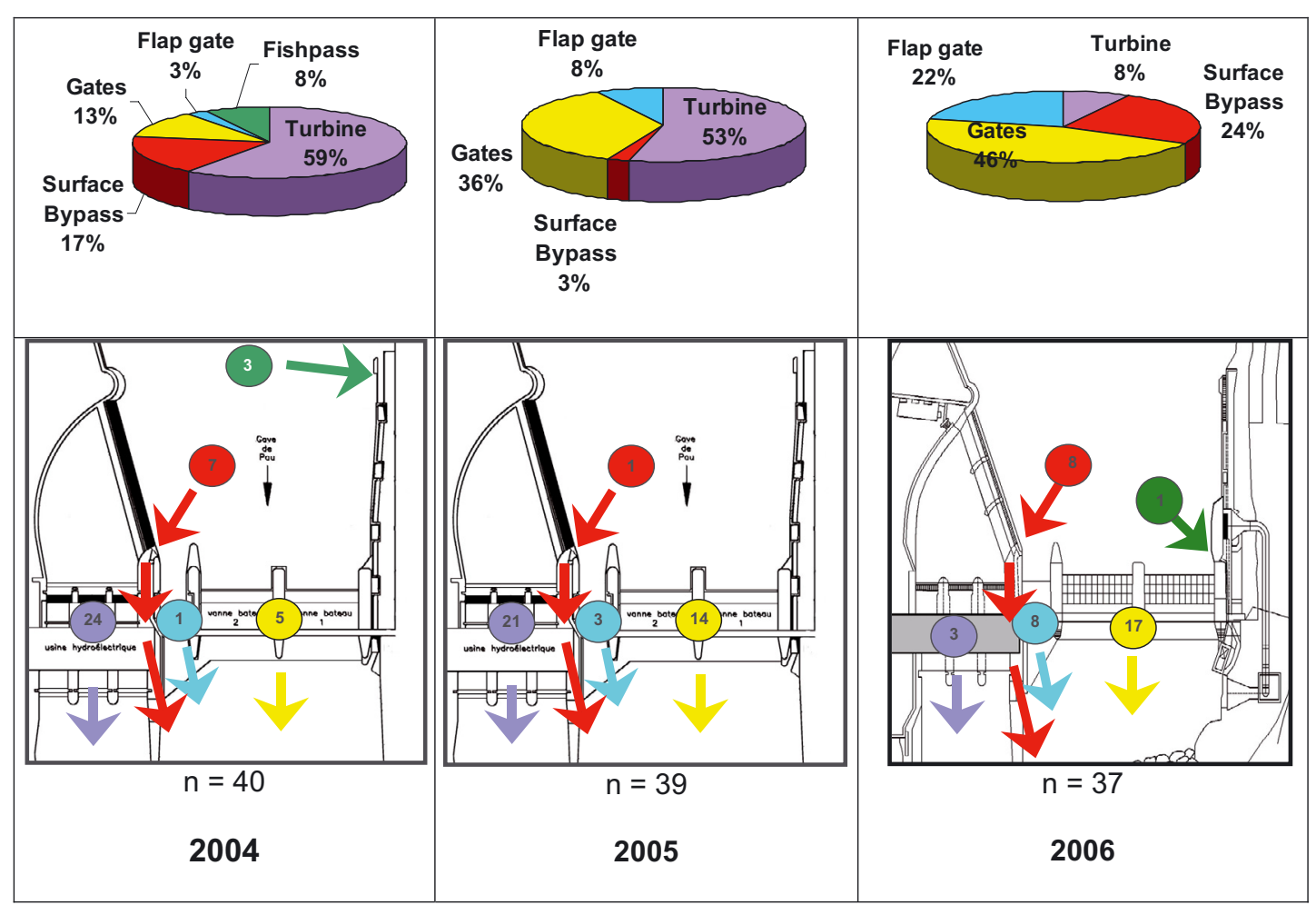

\section{Figure 4}

Passage routes at the Baigts plant from 2004 to 2006. The number of tagged eels using the various routes is shown on the lower figures.

\section{Figure 4}

Voies de franchissement de l'usine de Baigts de 2004 à 2006. Le nombre d'anguilles radiopistées ayant emprunté les diverses voies de franchissement est porté dans les figures du bas.

The main intake has a surface downstream migration bypass located at the downstream extremity of the trashrack (Figures 2 and 3). The entrance of the bypass is an opening $2 \mathrm{~m}$ wide and $1 \mathrm{~m}$ deep. Bypass flow is $2.2 \mathrm{~m}^{3} \cdot \mathrm{s}^{-1}$ (2.4\% of the maximum plant intake flow rate) and the flow velocity at the entrance is approximately $1 \mathrm{~m} \cdot \mathrm{s}^{-1}$. An open channel flume $45 \mathrm{~m}$ long is used to convey fish from the bypass entrance to the tailwater. This surface bypass was used for the first (2004) and third (2006) studies. For the second study (2005), the surface bypass was converted into a deep bypass by installing a semi-cylindrical mask in front of it (Figure 3). The lower part of this mask, i.e. the bypass entrance, opens at the elevation of the base of the intake trashrack (i.e. $7 \mathrm{~m}$ below the level of the reservoir). The flow discharge of this bypass was roughly the same as that of the surface bypass.

The intake for the mini-power plant has two downstream surface bypasses $(0.8 \mathrm{~m}$ wide and $0.65 \mathrm{~m}$ deep), located on either side of the intake trashrack, and one deep bypass $(0.8 \mathrm{~m}$ wide $\times 1 \mathrm{~m}$ high), located on the trashrack's right-bank side, approximately $1 \mathrm{~m}$ above the reservoir bed (Figures 3 and 4). The maximum flow delivered by all the bypasses $\left(0.5 \mathrm{~m}^{3} \cdot \mathrm{s}^{-1}\right)$ accounts for $4 \%$ of the turbine capacity. The $0.5 \mathrm{~m}^{3} \cdot \mathrm{s}^{-1}$ bypassed flow was delivered every other day by the two surface bypasses $\left(0.25 \mathrm{~m}^{3} \cdot \mathrm{s}^{-1}\right.$ for each bypass $)$ or by the deep bypass. The velocity at the entrance was around $0.5 \mathrm{~m} \cdot \mathrm{s}^{-1}$ for the surface bypasses and $1 \mathrm{~m} \cdot \mathrm{s}^{-1}$ for the deep bypass. An old Denil fish pass (flow discharge around $0.5 \mathrm{~m}^{3} \cdot \mathrm{s}^{-1}$ ), $80 \mathrm{~m}$ long, is located on the left bank, and operated during the 2004 and 2005 studies (Figure 2). 


\section{> FISH TAGGING AND ENVIRONMENTAL RECORDS}

Since there is no downstream migration trap on the Gave de Pau basin, eels could only have been caught by electrofishing, which would have resulted in uncertainty as to the status of their silvering and their capacity to migrate downstream once tagged and released. For this reason, the eels came from professional silver eel fisheries on the Loire River and on a small river $50 \mathrm{~km}$ from Baigts. After being transported, the eels were kept for several days to several weeks in 2-m-diameter circular tanks supplied with water from the river.

The fish were anaesthetised by electronarcosis using the technique developed by Gosset and Garaïcoechea (1974), where fish are placed in a tank between two electrodes delivering a continuous electrical current of $40-80 \mathrm{~V}$. An ATS (Advanced Telemetry System) radio transmitter (frequency 48-49 MHz, length $45 \mathrm{~mm}$, diameter $11 \mathrm{~mm}$, weight $8 \mathrm{~g}$, life 4 months) was implanted in the body cavity by surgical incision as described by Baras and Jeandrain (1998) and Gosset and Rives (2005). At the same time the fish were PIT-tagged with a glassencapsulated transponder (TIRIS RI-TRP-RR2B, length $32 \mathrm{~mm}$, diameter $3 \mathrm{~mm}$, weight $0.8 \mathrm{~g}$ ), inserted in the body cavity next to the radio transmitter. The total length and the width of the head were measured before tagging.

The eels were kept under observation in tanks for at least $24 \mathrm{~h}$, then released into the Gave de Pau at three points $2.8 \mathrm{~km}, 5.7 \mathrm{~km}$ and $7.5 \mathrm{~km}$ above the hydroelectric facility. They were released in batches of 2-6 eels, depending on the number of tagged eels remaining in the reach, in order to limit the monitoring to a maximum of 4 or 8 radio frequencies on each of the datalogging radio receivers (depending on the volume of the detection zone).

Hand-held radio receivers (ATS-R2100) with loop or whip antennae were used regularly (every $0.5-2$ days) to identify the eels' position in the river. Static receivers connected to either aerialloop or immersed-wire antennae and linked to digital data loggers (ATS-D5041A and DCC II) were also deployed in order to detect fish entering and leaving calibrated zones and thus to track their movements. Fourteen reception zones of different dimensions were established at the Baigts site (Figure 2). Several large zones were established to detect the presence of eels in the forebay and to determine the passage routes (via the flood gates, the surface flap gate, the turbines of the right-bank powerhouse and the left-bank mini-plant, and the old upstream fishway). In order to monitor eel behaviour in more detail at the intake, small zones (of only a few metres) were established along the trashrack for the right-bank plant (zones A to E) and around the downstream migration bypass (BP). Some strategic passageways of limited size (including bypasses and trash troughs) were fitted with PIT detection antennae.

Environmental parameters, including water temperature, conductivity, turbidity, atmospheric pressure, rain and direct sunlight, were recorded hourly using automatic data loggers. The flow rates into the various structures (turbines and gates) of each plant were provided by EDF. The daily river flow discharge was obtained from the Pont de Berenx gauging station located about $1 \mathrm{~km}$ downstream from Baigts.

\section{> STUDY DESIGN}

The three experiments were run during the downstream migration period (October to February) (Table I). For the 2004 study 40 eels were radio-tracked; mean body length and head width were $610 \mathrm{~mm}$ and $24 \mathrm{~mm}$, respectively (Table II). For the 2005 study, during which 39 eels (mean length $646 \mathrm{~mm}$ and mean head width $27 \mathrm{~mm}$ ) were tracked, the surface bypass of the main intake was configured as a deep bypass. The surface bypass was reinstalled for the 2006 study, during which 37 eels, significantly larger (mean body length $840 \mathrm{~mm}$, mean head width $34 \mathrm{~mm}$ ) than those of the two preceding studies, were tracked.

In 2004 and 2005, most eels tagged (95\% and 80\%, respectively) had heads with a width of less than the $30-\mathrm{mm}$ gap between the bars of the main intake trashrack; in $2006,76 \%$ of the eels had a head broader than $30 \mathrm{~mm}$ (Table II). 


\section{Table I}

Number of eels tagged and period of tracking for experiments in 2004, 2005 and 2006.

Tableau I

Nombre d'anguilles radio-pistées et périodes de suivi lors des expérimentations de 2004, 2005 et 2006.

\begin{tabular}{|l|c|c|c|}
\hline Year & No. of radio-tracked eels & No. of batches released & Period of tracking \\
\hline $\mathbf{2 0 0 4}$ & 40 & 12 & from 29/10/04 to 19/01/05 \\
$\mathbf{2 0 0 5}$ & 39 & 17 & from 10/11/05 to 13/02/06 \\
$\mathbf{2 0 0 6}$ & 37 & 11 & from 21/11/06 to 06/04/07 \\
\hline TOTAL & 116 & 40 & \\
\hline
\end{tabular}

\section{Table II}

Characteristics of eels radio-tracked during the three years of experimental work.

\section{Tableau II}

Caractéristiques des anguilles radiopistées lors des trois années d'expérimentation.

\begin{tabular}{|c|c|c|c|c|c|c|c|c|}
\hline Year & \multicolumn{3}{|c|}{ Total length $(\mathrm{mm})$} & \multicolumn{3}{c|}{ Head width $(\mathrm{mm})$} & \multicolumn{2}{c|}{ No. of eels with head width } \\
\hline & Min. & Max. & Mean & Min. & Max. & Mean & $<30 \mathrm{~mm}$ & $>30 \mathrm{~mm}$ \\
\hline $\mathbf{2 0 0 4}$ & 540 & 750 & 610 & 19 & 32 & 24 & 38 & 2 \\
$\mathbf{2 0 0 5}$ & 500 & 990 & 646 & 16 & 46 & 27 & 31 & 8 \\
$\mathbf{2 0 0 6}$ & 620 & 1100 & 840 & 21 & 48 & 34 & 9 & 28 \\
\hline
\end{tabular}

Table III

Passage routes at the Baigts plant from 2004 to 2006.

Tableau III

Voies de franchissement de l'usine de Baigts de 2004 à 2006.

\begin{tabular}{|c|c|c|c|c|}
\hline Year & 2004 & 2005 & 2006 & Total \\
\hline No. of tracked eels & 40 & 39 & 37 & 116 \\
\hline $\begin{array}{l}\text { Escapement (passage through spillways } \\
\text { or bypasses) }\end{array}$ & $16(40 \%)$ & $18(46.1 \%)$ & $34(91.9 \%)$ & $68(58.6 \%)$ \\
\hline Turbines (total) & $24(60 \%)$ & $21(53.9 \%)$ & $3(8.1 \%)$ & $48(41.4 \%)$ \\
\hline Main turbines (right bank) & $24(60 \%)$ & $21(53.9 \%)$ & $3(8.1 \%)$ & $48(41.4 \%)$ \\
\hline Mini-plant turbines (left bank) & - & - & $0(0 \%)$ & $0(0 \%)$ \\
\hline Downstream bypasses (total) & $7(17.5 \%)$ & $1(2.5 \%)$ & $9(24.3 \%)$ & $17(14.7 \%)$ \\
\hline Main intake bypass (right bank) & $7(17.5 \%)$ & $1(2.5 \%)$ & $8(21.6 \%)$ & $16(13.8 \%)$ \\
\hline Mini-plant bypasses (left bank) & - & - & $1(2.7 \%)$ & $1(0.9 \%)$ \\
\hline Spillways (total) & $6(15 \%)$ & $17(43.6 \%)$ & $25(67.6 \%)$ & $48(41.4 \%)$ \\
\hline Spill gates & $5(12.5 \%)$ & $14(35.9 \%)$ & $17(46 \%)$ & $36(31 \%)$ \\
\hline Flap gate & $1(2.5 \%)$ & $3(7.7 \%)$ & $8(21.6 \%)$ & $12(10.3 \%)$ \\
\hline Old fish pass & $3(7.5 \%)$ & - & - & $3(2.6 \%)$ \\
\hline
\end{tabular}

\section{RESULTS}

\section{> DOWNSTREAM PASSAGE}

\section{Escapement rates and passage routes}

The escapement rate was defined as the proportion of eels that pass the facility other than via the turbines (i.e. via spillways or bypasses). The escapement rates were $40 \%, 46 \%$ and 92\%, respectively, in the years 2004, 2005 and 2006 (Table III).

The passage routes (Figures 4 and 5, and Table III) varied markedly depending on the year of study:

- In 2004, most eels (60\%) passed through the turbines. The remainder passed in roughly equal numbers via the surface bypass (17.5\%) and the spillways (15\%). A few eels (3 eels) passed via the old upstream fish ladder on the forebay's left bank $\left(1 \mathrm{~m}^{3} \cdot \mathrm{s}^{-1}\right)$. 
- In 2005, as in 2004, most eels went through the turbines (53.9\%), and only one eel passed via the deep bypass. On the other hand, many more than in 2004 passed via the spillways (43.6\%).

- In 2006, only $8.1 \%$ passed via the turbines. They used the surface bypass of the main intake (21.6\%) with much the same frequency as they did in 2004 (17.5\%). Most eels $(67.6 \%)$ passed via the spillways, although one (2.7\%) passed via the downstream surface bypasses of the mini-plant on the left bank.

Over the three years, several eels were monitored at or near the trashracks ( 21 at the main intake and 20 at the left-bank intake). Judging by the fact that no fish were recorded in the trash troughs, it is assumed that none became impinged on the screens.

\section{>INFLUENCE OF ENVIRONMENTAL FACTORS ON PASSAGE}

\section{River flow and passage}

The downstream migration behaviour of eels relocated upstream of the plant appeared to be highly dependent on environmental factors. The most active migration, with a high net downstream migration speed in the river, occurred during increases in river flow. These flow increases did not necessarily coincide with flood events, since the peak flow discharge recorded remained relatively modest in most of the events. Outside of these flow increases, the eels remained relatively inactive for periods ranging from several days to several weeks, with only slow and "exploratory" movements and prolonged pauses in certain clearly-defined areas.

River flow discharges at which eels passed the facility varied from 30 to $300 \mathrm{~m}^{3} \cdot \mathrm{s}^{-1}$ (Figure 5). A large proportion of the eels (53\%, or 62 fish) passed the facility during rising flows and in a state of "active" migration, but a significant proportion (47\%, or 54 fish) passed during nearly constant river flow conditions. In 2005 and 2006 there were many more passages $(68 \%$ and $81 \%)$ during rising river flow than during constant river flow conditions (32\% and $19 \%)$. In 2004 almost the same number of passages took place during rising river flow (48\%) as during nearly constant river flow (52\%).

\section{Effect of the nycthemeral cycle}

Most passages took place at dusk and during the night (Figure 6). Of the 116 eels passing the plant during the three studies, $70 \%$ crossed at night (7.00 p.m. -7.00 a.m.), $8 \%$ at dusk (5.00 p.m. -7.00 p.m.) and $22 \%$ during the day (7.00 a.m. -4.00 p.m.). Most of the 26 eels that crossed during the day did so during a river flow increase $(85 \% ; 22 / 26$ eels) when water turbidity was higher. Day crossings took place mainly (58\%; $15 / 26$ eels) at midday (11.00 a.m.-1.00 p.m.).

\section{> CHARACTERISATION OF DOWNSTREAM PASSAGE BEHAVIOUR}

The behaviour of eels approaching the Baigts hydroelectric facility could be characterised by the number of site incursions eels made before passage, the delay before their passage, and, as an indicator of their level of exploration of the site, the number of recording zones they visited (Figure 2).

A site incursion is defined as an entry into the most upstream detection zone which extends into the forebay roughly $150 \mathrm{~m}$ upstream of the dam. Eels generally fell into two groups, those making single incursions and those making multiple incursions. Eels making multiple incursions were those that explored the facility, then returned to the river upstream of this detection zone and came back later. These eels generally returned upstream no more than 

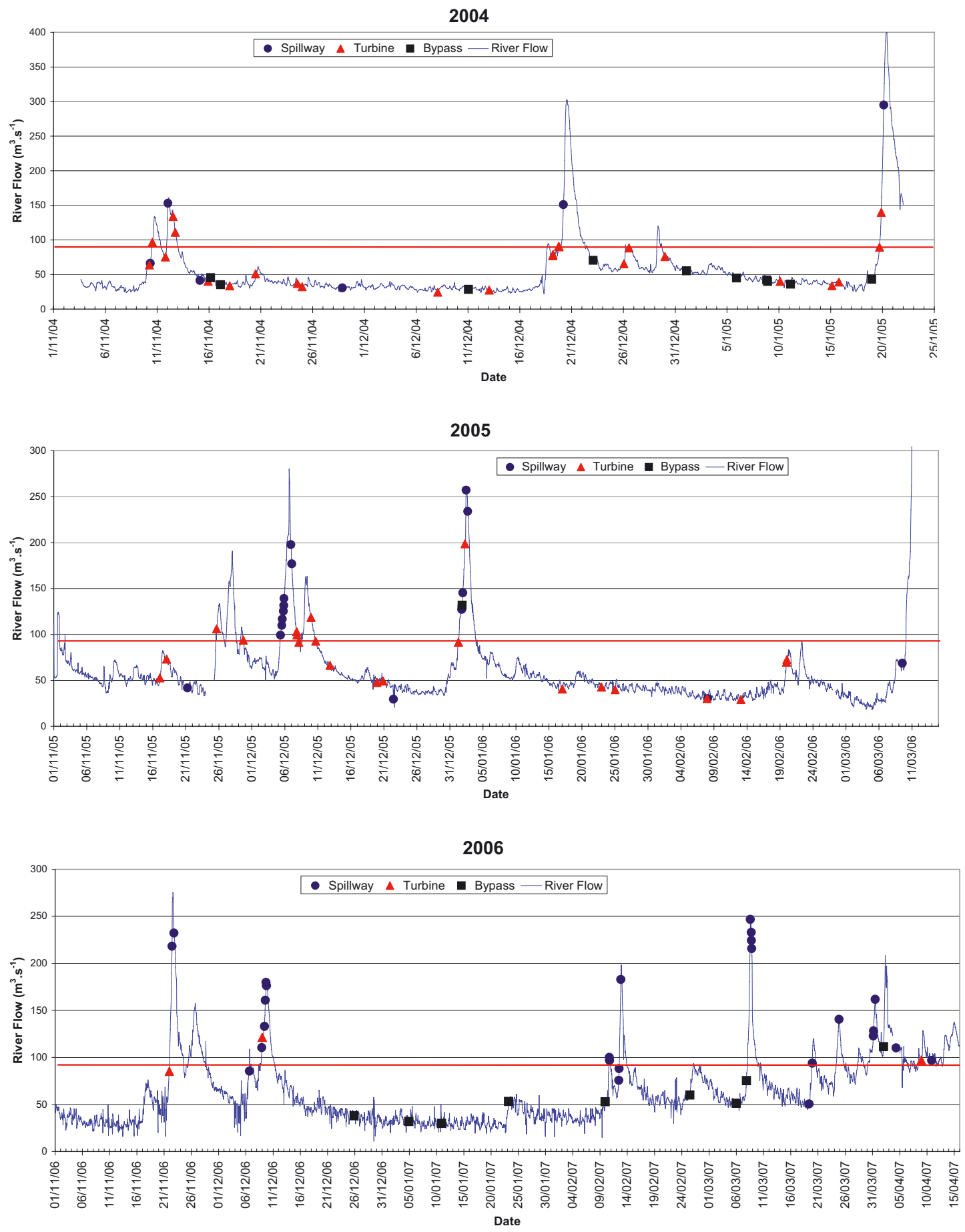

Figure 5

Passage routes for the Baigts plant and flow rate in the Gave de Pau river between 2004 and 2006. Each symbol represents the passage of a radio-tracked eel by one of the various passageways.

Figure 5

Voies de franchissement de l'usine de Baigts et débit du Gave de Pau de 2004 à 2006. Chaque symbole matérialise le franchissement d'une anguille radiopistée par l'une des diverses voies de franchissement. 


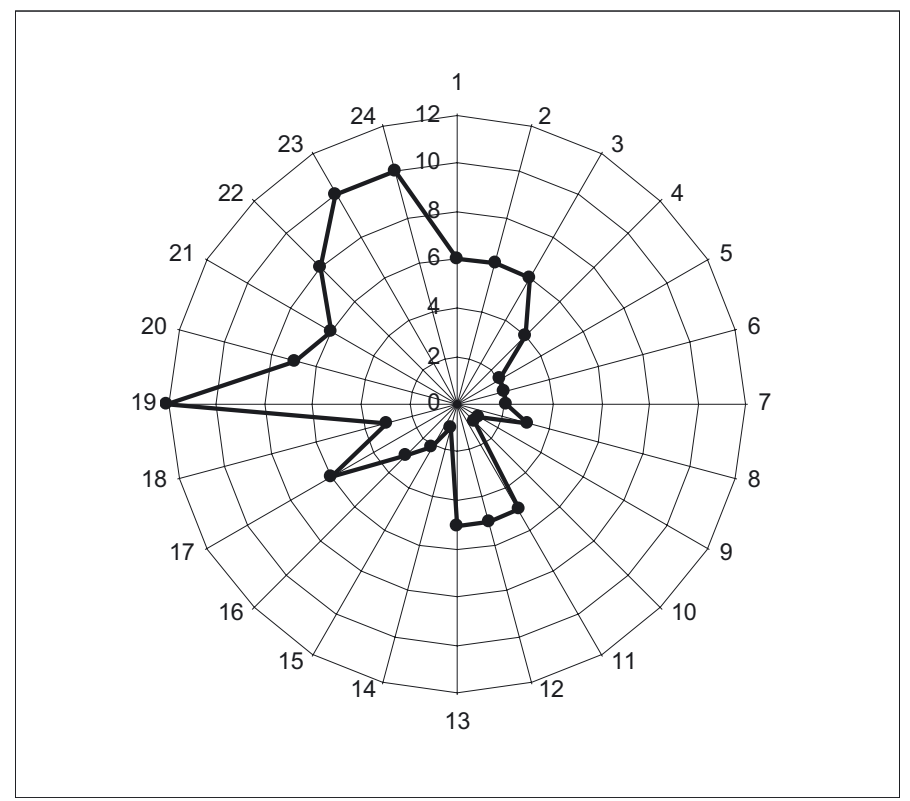

Figure 6

Time of passages of the Baigts hydroelectric facility from 2004 to 2006.

Figure 6

Heures de franchissement de l'aménagement de Baigts de 2004 à 2006.

a few hundred metres from the facility (maximum distance: $2.8 \mathrm{~km}$ ). Eels that stayed in the forebay zone, even for a significant time, are considered to have made a single site incursion. Some eels passed directly and quickly through the trashrack without exploration; others "explored" the trashrack cross-section by making multiple incursions (i.e. they came close to the trashrack then went back to the forebay) and by moving along the rack, thus visiting the different radio-tracking zones of the rack (zones $A, B, C, D, E-$ Figure 2).

Behaviour of eels near or at the trashrack of the main intake may be characterised by the cumulative time spent at or near the trashrack, the number of incursions to the front of the trashrack, the number of zones explored along the trashrack, and by the time between the first incursion to the trashrack and downstream passage.

Based on behaviour in the forebay, at the trashrack, and on the passage route, five types of behaviour ( $\mathrm{C} 1$ to $\mathrm{C5}$ ), shown diagrammatically in Figure 7, were distinguished for 112 of the 116 tagged eels:

- C1 (17\% of eels): passed through quickly and directly via spillways (gates or flap gate) without visiting the intake trashracks. These eels visited the site only once, took a short time to cross (median: $6 \mathrm{~min}$, 1st quartile: $4 \mathrm{~min}$, 3rd quartile: $15 \mathrm{~min}$ ), and visited few zones $(2,1,3)^{2}$;

- C2 (25\% of eels): passed through quickly and directly via the turbines, without exploring other passage routes (bypass, gates or flap gate). Most of these eels passed the facility on their first site incursion, taking a short time to pass (11 min, $4 \mathrm{~min}, 15 \mathrm{~min}$ ) and visiting only one zone $(1,1,2)$. They passed very rapidly through the racks (3.5 $\mathrm{min}, 2.6 \mathrm{~min}, 6.7 \mathrm{~min})$, were only in contact with the racks for a very short time $(0.5 \mathrm{~min}, 0.32 \mathrm{~min}, 1.3 \mathrm{~min})$ and only explored them to a very limited extent (number of zones explored: 2, 1, 3). They generally passed through the rack on their first approach;

- C3 (16\% of eels): passed through relatively quickly via the turbines, but after exploring other passage routes (trashracks, bypass, gates and flap gate). This group differed from

\footnotetext{
${ }^{2}$ Notation used to characterise behaviour (duration, number of incursions, etc.): $\left(P_{50}, P_{25}, P_{75}\right)$ where $\mathrm{P}_{50}=$ median, $\mathrm{P}_{25}=1$ st quartile and $\mathrm{P}_{75}=$ 3rd quartile of the variable $\mathrm{P}$.
} 


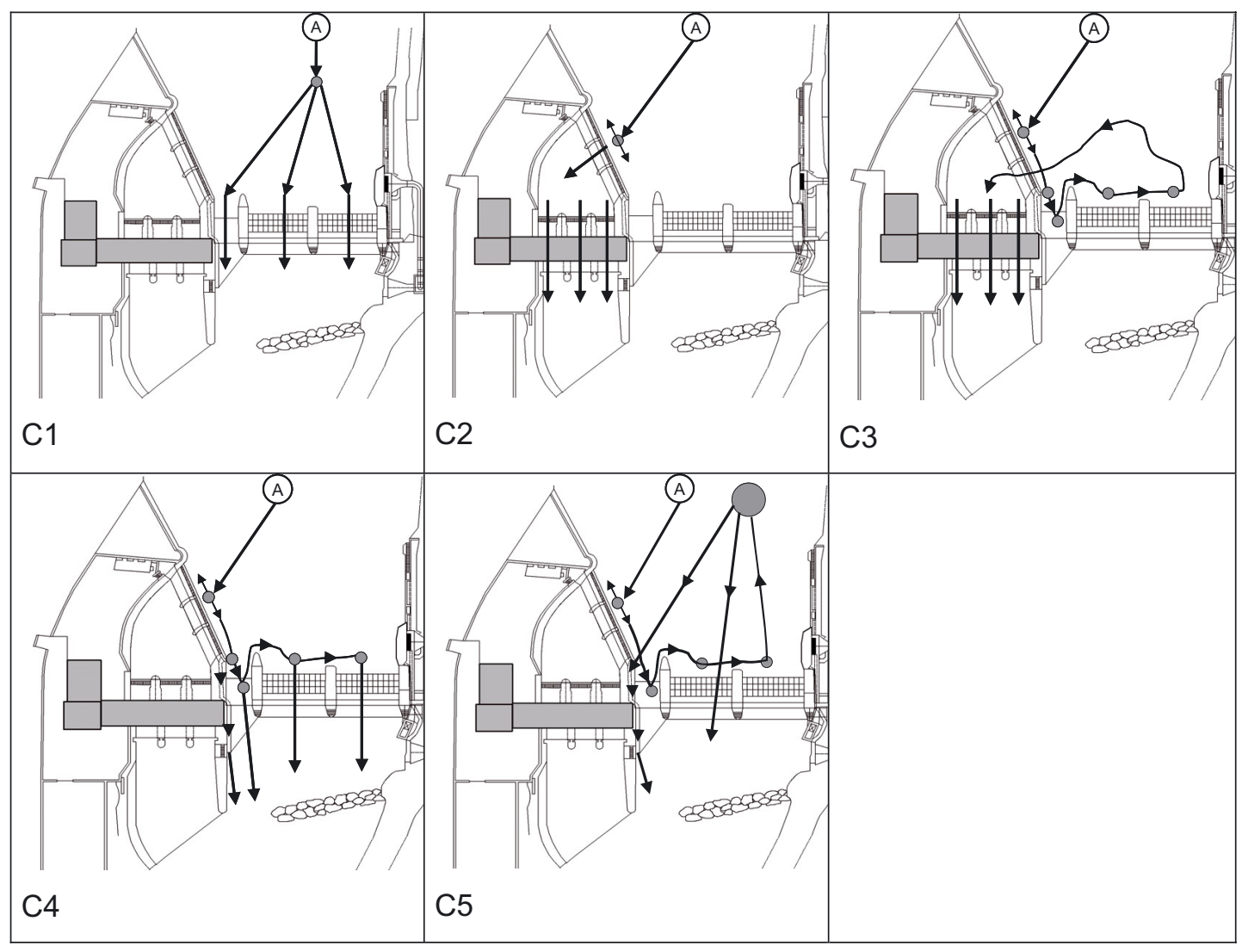

Figure 7

Schematic overview of the various types of eel behaviour observed in the forebay. $A=$ path during first approach to the site.

Figure 7

Représentation schématique des divers types de comportement des anguilles observés à l'amont de l'usine de Baigts. $\mathrm{A}=$ trajet lors de la première arrivée sur le site.

C2 in that the eels made more multiple site incursions into the site (32\% of eels) and passage delays were longer ( $1.75 \mathrm{~h}, 0.6 \mathrm{~h}, 22 \mathrm{~h})$. Eels explored more zones upstream $(5,4,18)$, passed less quickly through the racks (53 min, $9.6 \mathrm{~min}$ and $17 \mathrm{~h}$ ), made more incursions into the zones in front of the rack $(4,2,16)$, and stayed at or near the racks for longer (3.5 min, $1.3 \mathrm{~min}, 11.6 \mathrm{~min})$;

- C4 (15.5\% of eels): passed through via the spillway or bypass after exploring the trashracks. Compared with group $\mathrm{C} 3$, fewer eels (11\%) made multiple site incursions, but the passage delays (1.6 h, $0.45 \mathrm{~h}, 19 \mathrm{~h})$, and the number of zones they explored (2.5, $2,11)$ are of the same order of magnitude. They also took a similar time to pass (80 min, $4.2 \mathrm{~min}, 17 \mathrm{~h}$ ). Although the group made a comparable number of incursions onto the trashrack with C3 $(4,1,9)$, eels spent less time at or near the trashrack (1.2 min, $0.30 \mathrm{~min}$ and $3.8 \mathrm{~min}$ );

- C5 (22.5\% of eels): passed through the facility via the spillway or bypass, but after staying a long time upstream of the plant. Compared with the preceding groups (C1 to C4), more eels (46\%) made multiple site incursions; passage delays were much longer (137 h, 72 h, 212 h); more zones were explored upstream of the plant $(26,13,40)$; and more incursions were made onto the trashrack $(9,3,25)$. Eels stayed longer at or near the trashrack (3.8 $\mathrm{min}, 1.2 \mathrm{~min}, 10.9 \mathrm{~min}$ ) and explored more zones along the rack $(9,3,25)$. 


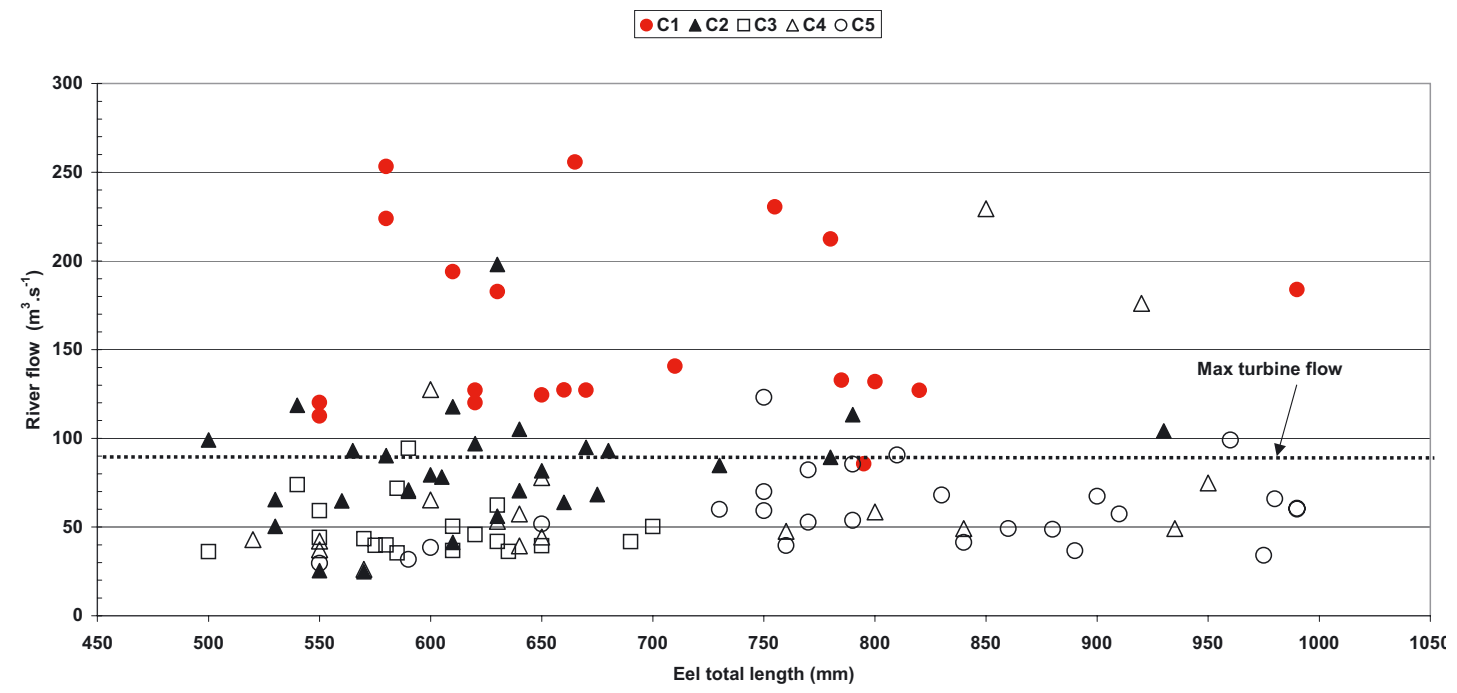

\section{Figure 8}

Types of eel behaviour at the Baigts site, as a function of eel body length and river flow as the eels arrive at the facility. The different types of eel behaviour (C1 to C5) are shown schematically in Figure 7.

\section{Figure 8}

Types de comportement des anguilles sur le site de Baigts en fonction de la taille des anguilles et du débit du Gave de Pau lors de leur arrivée. Les divers types de comportement (C1 à C5) sont schématisés sur la Figure 7.

Figure 8 illustrates the relationship between river flow discharge when eels arrived in front of the facility, fish length and type of behaviour:

- Direct escapement via the spillways $(C 1)$ occurred when the river flow was higher than approximately $100-120 \mathrm{~m}^{3} \cdot \mathrm{s}^{-1}$, corresponding to a spill flow of over $10-30 \mathrm{~m}^{3} \cdot \mathrm{s}^{-1}$;

- Direct passage through the turbines (C2) occurred when the river flow was near or slightly higher than the maximum turbine discharge of the plant $\left(90 \mathrm{~m}^{3} \cdot \mathrm{s}^{-1}\right)$, corresponding to a high flow through the turbines and a low spill discharge. These were mainly smaller eels;

- Passage through the turbines after exploring other passage routes (C3) was generally restricted to small eels and occurred during low river flow, i.e. when there is no spill and the turbine discharge takes the whole river flow, except the flow through the downstream bypasses and the old fish pass;

- Passage via the spillways or bypass after visiting the intake trashrack (C4), occurring in conditions similar to those for behaviour C3, was usually exhibited by larger eels;

- Escapement via the spillways and bypass after a long stay upstream of the facility (C5) occurred mostly amongst large eels which cannot pass through the trashracks and arrive during periods of low river flow, i.e. with little or no spill flow.

Some of the conclusions drawn from Figure 8 can be confirmed by statistical analysis. The river flows at which the five types of behaviour are observed were significantly different (Figure 9A) (ANOVA, $F=28.1, p<0.05$ ). Eels escaped directly via the spillways $(C 1)$ when discharge flow in the river was higher than for other classes of behaviour: the mean flow rates for $\mathrm{C} 1\left(160 \mathrm{~m}^{3} \cdot \mathrm{s}^{-1}\right)$ differed significantly (Bonferroni test for multiple comparisons, $p<0.05$ ) from those for the other groups C2, C3, C4 and C5 (means of 83, 52, 75 and $60 \mathrm{~m}^{3} \cdot \mathrm{s}^{-1}$, respectively). Among the other behaviours, only C2 and C3 occurred at significantly different (Bonferroni, $p<0.05$ ) river discharges (means of $83 \mathrm{~m}^{3} \cdot \mathrm{s}^{-1}$ and $52 \mathrm{~m}^{3} \cdot \mathrm{s}^{-1}$ ).

Eel behaviour also differed significantly depending on their length (Figure 9B) (ANOVA, $F=$ 13.7; $p<0.001$ ). Eels passing the scheme via the spillways or bypass after remaining a long time upstream of it (group C5) were significantly longer (average $810 \mathrm{~mm}$ ) than those 


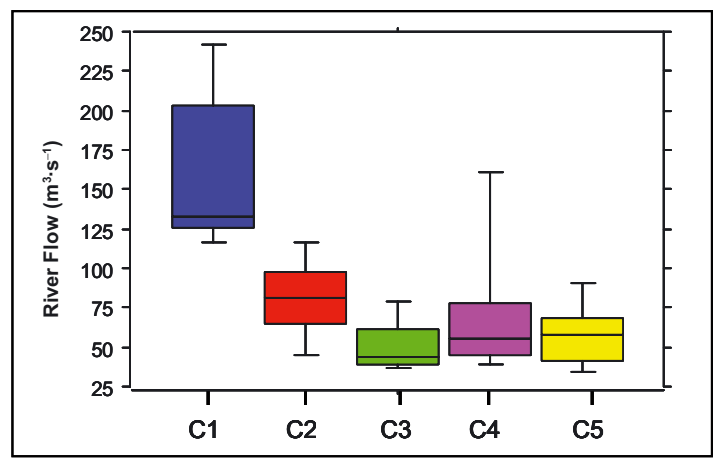

A

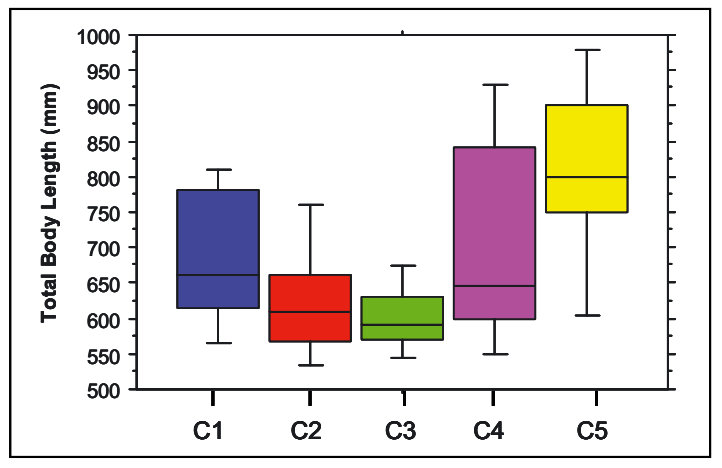

B

\section{Figure 9}

Type of behaviour exhibited in the Baigts power station forebay as a function of A) river flow and B) body length as eels arrive at the Baigts scheme. See Figure 7 for description of eel behaviour C1-C5.

\section{Figure 9}

Type de comportement des anguilles en amont de l'aménagement de Baigts en fonction A) de la longueur des individus et B) du débit du Gave de Pau lors de l'arrivée sur l'aménagement de Baigts. Se reporter à la figure 7 pour la description des comportements C1-C5.

in the other groups C1, C2, C3 and C4 (averages 691, 629, 600 and $703 \mathrm{~mm}$, respectively) (Bonferroni, $p<0.05$ ) (Figure 9B). The length of eels in group C2 (which passed directly and very quickly via the turbines) did not differ significantly (Bonferroni, $p<0.05$ ) from those in group C3 (that passed via the turbines after exploring the rack). By contrast, the length of eels in group C4 (that escaped after exploring the rack) was significantly higher than that of eels in group $\mathrm{C} 3$.

\section{$>$ MODELLING ESCAPEMENT}

Escapement via spillways or bypasses and passage through the turbines was modelled using logistic regression (Hosmer and Lemeshow, 2000). A linear combination of the two variables $Q_{\text {spill }} / Q_{\text {tot }}$ (the ratio of spill flow to total river flow) and $T L$ (the total length of eels in $\mathrm{mm}$ ) was used to explain the binary response variable (escapement/passage via the turbines). These two independent variables are the only variables significantly influencing the escapement probability at the dam.

The expression for the escapement probability (P) (i.e. passage via the spillways or bypass) for an eel of length TL is:

$$
\mathrm{P}=\exp (\eta) /(1+\exp (\eta)) \quad \text { where: } \quad \eta=-6.89+4.28\left(\mathrm{Q}_{\mathrm{spill}} / \mathrm{Q}_{\mathrm{tot}}\right)+0.0091 \mathrm{TL} .
$$

A chi-square test (chi-square $=8.38$ with 6 degrees of freedom, $p=0.211$ ) shows that with a confidence level of $90 \%$, there is no reason to reject the model's goodness of fit, since the probability is greater than or equal to 0.10 .

The model correctly classifies $84 \%$ of the passages of eels via spillways or turbines.

Figure 10 shows the relationship between the spill flow and the probability of escapement for eels of minimum, average and maximum length in the sample studied.

\section{> PASSAGES VIA BYPASSES}

Of the 116 eels radio-tracked between 2004 and 2006, 16 (13.8\%) passed via the main intake downstream bypass (surface or deep). Fifteen of them used the surface bypass in 2004 
F. Travade et al.: Knowl. Managt. Aquatic Ecosyst. (2010) 398, 01
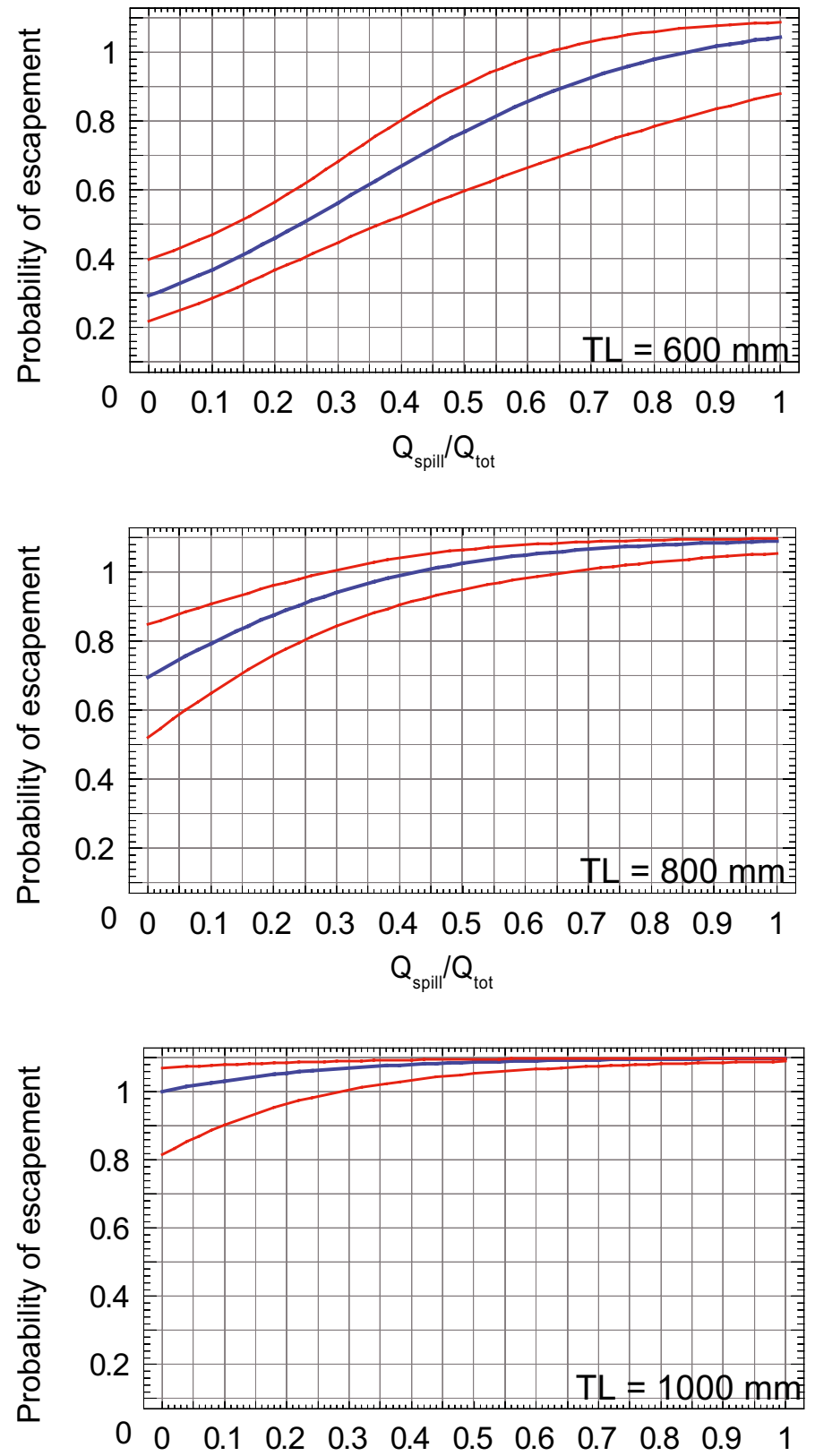

Figure 10

Escapement probabilities (passage via a route other than turbines) at the Baigts plant as a function of the ratio $Q_{\text {spill }} / Q_{\text {tot }}$ (ratio of spill flow/river flow) for eels with $T L$ (total body length) $600 \mathrm{~mm}, 800 \mathrm{~mm}$ and $1000 \mathrm{~mm}$. The two outside red lines show the $90 \%$ confidence interval for the escapement probability.

Figure 10

Probabilités d'échappement (passages par les évacuateurs de crue et l'exutoire de dévalaison) des anguilles à l'usine de Baigts en fonction du rapport $Q_{\text {spill }} / Q_{\text {tot }}$ (ratio débit déversé/débit du Gave) pour des anguilles de taille TL (longueur totale du corps) de $600 \mathrm{~mm}, 800 \mathrm{~mm}$ et $1000 \mathrm{~mm}$. Les courbes en rouge représentent l'intervalle de confiance à $90 \%$ de la probabilité d'échappement. 


\section{Table IV}

Passage of eels via the bypasses for the main generating plant from 2004 to 2006. (a) \% of tagged eels; (b) \% of eels arriving near the racks; (c) \% of eels arriving in the bypass reception zone.

\section{Tableau IV}

Passage des anguilles par les exutoires de l'usine principale (rive droite) de 2004 à 2006. (a) : \% par rapport aux anguilles marquées; (b) : \% par rapport aux anguilles venues aux grilles; (c) : \% par rapport aux anguilles venues dans la zone de réception de l'exutoire.

\begin{tabular}{|c|c|c|c|c|}
\hline & 2004 & 2005 & 2006 & Total \\
\hline Type of downstream bypass & surface & deep & surface & \\
\hline No. of tracked eels & 40 & 39 & 37 & 116 \\
\hline $\begin{array}{l}\text { No. of tracked eels that went near } \\
\text { the main intake trashrack (right bank) }\end{array}$ & 37 & 28 & 27 & 92 \\
\hline $\begin{array}{l}\text { No. (\%) of eels that went near } \\
\text { the bypass entrance (a) }\end{array}$ & 13 (35.1\%) & 14 (50\%) & 23 (88.8\%) & 50 (54.3\%) \\
\hline Passage through the bypass (a) & $7(17.5 \%)$ & $1(2.6 \%)$ & $8(21.6 \%)$ & $16(13.8 \%)$ \\
\hline (b) & $8.9 \%$ & $3.6 \%$ & $29.6 \%$ & $17.4 \%$ \\
\hline (c) & $53.8 \%$ & $7.1 \%$ & $33.3 \%$ & $30.2 \%$ \\
\hline
\end{tabular}

and 2006 and only one used the deep bypass in operation in 2005. In 2006, when the miniplant came into service, only one eel of the 37 radio-tracked went through one of the plant's three bypasses (Table IV). During the 2004 experimental study, 3 of the 40 radio-tracked eels $(7.5 \%)$ used the old fish ladder (Figure 2, Table IV). In total, over the three years of experiments, 20 eels (17.2\%) passed the facility using safe routes other than spillways (downstream bypasses or the fish pass).

Only $33 \%$ to $54 \%$, according to the year, of the eels visiting the entrance of the surface bypass at the main plant passed through it (Table IV). The 15 eels that used the main surface bypass did so after several visits $(4,2,8)$ to the bypass entrance zone. The cumulative time of presence at the bypass entrance was low $(2.4 \mathrm{~min}, 0.66 \mathrm{~min}, 4.6 \mathrm{~min})$, but the delay between their arrival at the trashrack and their passage through the bypass was relatively long ( 3 days, $1.7 \mathrm{~h}, 3.9$ days). This delay was significantly lower (Mann-Whitney, $p<0.05$ ) for smaller eels $(T L<750 \mathrm{~mm}$ ) than for bigger eels (TL $>750 \mathrm{~mm}$ ): median, respectively, $2 \mathrm{~h}$ and 4.1 days.

\section{DISCUSSION - CONCLUSIONS}

Monitoring a sample of 116 eels over three years has enabled us to obtain relatively accurate answers to our questions. However, the radio telemetry methodology could not provide a sufficiently high-resolution description of the behaviour of eels and thus provide information concerning the depth at which eels migrated or passed through the intake trashracks, as might be done using 3D acoustic telemetry methods (Haro et al., 2000; Watene et al., 2003; Brown et al., 2009).

In common with other telemetric studies (Bruijs et al., 2003; Durif, 2003; Durif et al., 2003; Carr and Whoriskey, 2008), episodes of active downstream migration of eels were intermittent, and occurred during "environmental windows" that are related to increases in river discharge. Because the eels were released relatively near the hydroelectric facility (a few kilometres upstream), and with a variable delay between their catch and their release, the proportion of eels in "active" as opposed to "exploratory" migration when they arrived at the Baigts site was probably skewed compared with natural migration. This bias may have affected the results significantly, since the river flow as the eels arrive at the plant appears to be crucial in determining their route for passing through the scheme. It should be possible to reduce this bias in the follow-up to this study, currently in progress (Bau et al., 2008), where the eels are being released some $50 \mathrm{~km}$ upstream of Baigts. The effect of handling and tagging on the eels' behaviour in this study, particularly on the time they stay at the release point before migrating, is not known. However, it is considered to be minimal since those eels released during an increased river flow event migrated immediately, whereas eels released during a stable flow 
period stayed at the release point to await the next set of favourable environmental conditions before migrating.

Most passage by the eels was nocturnal and primarily took place during the first few hours after sunset. This appears to corroborate the generally nycthemeral pattern of downstream migration proposed by several authors (Tesh, 1977; Brown et al., 2009). As observed in a study on the Nive river in France (Durif, 2003), daytime passages almost always took place during increases in river discharge when turbidity was high, so such passages can be explained by low levels of light in the water.

The two main passage routes were through the turbines and via the gates during spills. Passage via the surface downstream bypasses, although less frequent, was nevertheless significant (averaging $21 \%$ for the two years when they were in operation). Total escapement rate through the spillways and the downstream bypasses (respectively $40 \%, 46 \%$ and $92 \%$ for 2004, 2005 and 2006) was shown to correlate closely with two key factors, the river discharge (in particular the spill flow as the eels arrive at the site), and the body length of eels. Based on observation, the following "passage patterns" were defined:

- During periods of high spill, the eels, whatever their body length, generally pass via the spillways. Most of them do not visit the trashracks.

- Large eels (TL > $800 \mathrm{~mm}$ ) are physically blocked by the $30-\mathrm{mm}$ intake trashracks. If there is no spill, and the only route is through the bypasses, they may remain upstream of the plant and be delayed for a relatively long time - stretching to several days.

- Small eels (TL $<600-650 \mathrm{~mm}$ ) cross the scheme very quickly. They pass either via the spillways or via the turbines, the proportion using each route depending on the ratio of spill flow/turbine flow. The trashrack seems to have little effect in impeding their migration, even when they pass the racks less quickly as a result of low river discharge.

- Intermediate-sized eels appear to be influenced more by the trashrack. When they pass through, they generally pass less quickly than small eels. They pass either via the spillways or via the turbines, the route taken depending on the ratio of spill flow/turbine flow. For the same spill flow/turbine flow ratio, proportionally fewer fish pass by the turbines compared with small eels.

The downstream surface bypass of the main power plant, which was originally designed for salmon, allowed 18\% (2004) and 22\% (2006) of eels to pass. By comparison, this same surface bypass, when tested around twelve years ago for juvenile salmon, allowed $45 \%$ of the smolts arriving in front of the water intake to pass (Chanseau et al., 2002). When the original surface bypass was converted into a deep bypass during the 2005 study, only a single eel passed through it. However, it should not necessarily be concluded from these results that a deep bypass is ineffective. Although its entrance was located some $7 \mathrm{~m}$ below the upstream water level and it was located at the same level as the lower extremity of the racks, it was still $5 \mathrm{~m}$ above the bed of the impoundment. In 1999, experiments carried out at the generating station in Halsou (on the Nive river), which tested two types of bypass located near the intake trashrack, showed that a bottom bypass, located on the river bed, was more effective than the surface bypass designed for salmon (Gosset et al., 2005).

The relative efficiency of surface bypasses and the eel behaviour (multiple visits to the surface bypass entrance) confirms the fact that, although eels are bottom-oriented species, they have a searching behaviour which includes vertical excursions. This has also been observed in other studies (Haro et al., 2000; Brown et al., 2009).

It might be questioned whether surface bypasses built for salmon can be of any use at hydropower plants similar to Baigts where the power intake is located at the dam without a headrace canal. This study at Baigts shows that the surface bypass can be a significant passage route for eels arriving at the intake, and that it helps reduce the migration delay for any large eels that are physically blocked by the racks. Without any bypasses, these eels would have to wait until the floodgates opened in order to be able to pass the facility. Furthermore, it also appears to be essential for the existing surface bypasses originally designed for salmon to be also operational during silver eel migrations at those hydropower plants with headrace canals, where the power intake represents a cul-de-sac. The role of these bypasses will be 
even more important where the trashracks have bars spaced sufficiently close to block the majority of eels.

The study showed that trashracks with bars $30 \mathrm{~mm}$ apart were practically impassable to eels longer than $800 \mathrm{~mm}$, whereas they were easily passable for eels shorter than $600 \mathrm{~mm}$. While the range between "easily passable" and "totally impassable" appears to be wide, there are several possible reasons to explain it. These could include: (i) the natural variation in the height and width of the body and head of different eels with the same length; (ii) spaces between bars that may not be uniform (some areas of the rack may be deformed); and (iii) the reluctance of some eels to cross the trashrack, which can depend on their motivation to migrate (greater reluctance to pass during stable flow in the river).

No eels, even the large ones physically blocked by the trashrack, were observed to become impinged on the trashrack bars, either at the main intake, or at the mini-plant. The approach velocity of the flow remained between $0.10 \mathrm{~m} \cdot \mathrm{s}^{-1}$ and $0.40 \mathrm{~m} \cdot \mathrm{s}^{-1}$ at the main water intake, and around $0.20 \mathrm{~m} \cdot \mathrm{s}^{-1}$ at the small water intake. These velocities are much lower than the maximum speeds $\left(V_{\max }=0.50 \mathrm{~m} \cdot \mathrm{s}^{-1}\right)$ recommended in Germany to avoid eel impingement on fine screens and consequent eel mortality (Adam et al., 1999; Pöhler, 2006).

The probabilities of escapement via the spillways were well described by logistic regression as a function of the variables $Q_{\text {spill }} / Q_{\text {tot }}$ (ratio of spill flow rate to total river flow) and $T L$ (body length of eels). It would be tempting to generalise this expression to other power plants and trashrack bar spacings by taking TL/spa (the ratio of the eel length to the space between the trashrack bars) as a variable in a logistic regression. However, it may not be possible to extrapolate the expression derived above to other sites, since the regression was established for a relatively limited range of values of TL/spa (between 20 and 35) and also implicitly takes into account the particular configuration of the Baigts intake. This study is continuing and includes the monitoring of six power plants (Bau et al., 2008), with very different characteristics in terms of site configurations and trashrack bar spacing. This should help define the relationships between the eels' escapement probability and the following parameters better: ratio of the spill flow to turbine flow, configuration of the hydropower plants, space between the trashrack bars and the body length of eels.

\section{> MANAGEMENT IMPLICATIONS}

This study confirms that the downstream migration behaviour of eels is strongly influenced by the flow conditions in the forebay of the hydropower facilities. While some eels are held up during their migration, and may make several approaches to the intakes, they are attracted by the dominant flow field that results in passage through the turbines if the flow is predominantly through the turbines and if the gaps between the bars of the intake are sufficiently wide. This confirms the results of other studies on downstream passage of silver eels (Haro et al., 2000; Behrmann-Godel and Eckmann, 2003; Brown et al., 2009). Surface downstream bypasses, originally designed for salmon, usually carry only a small percentage of the turbine flow and are not very efficient for eel passage. This is even more obvious where the racks are easier to get through. Creating safe alternatives for the downstream passage of eels requires reducing the space between trashrack bars to values significantly lower than $30 \mathrm{~mm}$, i.e. a maximum of $20 \mathrm{~mm}$, which will prevent the eels from passing, and associating this with sufficiently low approach velocities to avoid them being impinged on the racks. Alternatively, ensuring sufficient spill during downstream migration periods will help attract the eels to the spillways. The results of this study also suggest that a possible solution might be to partially close turbines rather than to shut them down totally. However, in order to avoid any significant losses in power production resulting from a reduction or shutdown of turbines throughout the eel migration season, the shutdown or partial closure of specific turbines would need to be accurately timed to reflect migration peaks. Accurate knowledge of this parameter is essential, in order to be able to evaluate the actual impact of given hydro plants on the migrating eel population and evaluate the potential benefit of this or other solutions such as reducing 
the spacing of trashrack bars. Future efforts to develop effective solutions for downstream migration should consider the benefit of long-term monitoring of natural downstream migration of silver eel.

\section{ACKNOWLEDGEMENTS}

The authors would like to thank the EDF GEH Adour et Gaves for permission to set up and conduct this study, and the staff at the Baigts power plant for their contribution and collaboration throughout the study. The technical help of Paul Thellier, Bruno Dupuis, Lamine Barbach from EDF R\&D, Francis Jalibert, Alain Borda, Stéphane Vighetti from ONEMA, Yannick Bory and David Clave from the migratory fish association MIGRADOUR was greatly appreciated for the hard and long telemetric work. We thank the anonymous reviewers for constructive comments on the manuscript. Special thanks to Greg Armstrong for his help in English language correction.

\section{REFERENCES}

Adam B., Schewers U. and Dumont U., 1999. Beitrage zum Schutz abwandernder Fische, Verhaltensbeobachtungen in einem Modellgerinne. Bibliotek Natur \& Wissenschaft Band, 16, 1-63.

Amaral S.V., Winchell F.C., McMahon B.J. and Dixon D.A., 2003. Evaluation of angled bar racks and louvers for guiding silver phase American eels. In: Dixon D.A. (ed.), Biology, Management, and Protection of Catadromous Eels, American Fisheries Society Symposium, 33, Bethesda, 367-376.

Baras E. and Jeandrain D., 1998. Evaluation of surgery procedures for tagging eel Anguilla anguilla (L.) with telemetry transmitters. Hydrobiologia, 371/372, 107-111.

Bau F., Gomes P., Bordes N., Larinier M., Travade F. and De Oliveira E., 2008. Suivi par radiopistage de la dévalaison de l'anguille argentée sur le Gave de Pau au niveau des ouvrages hydroélectriques d'Artix, Biron, Castetarbe, Baigts et Puyoo (2007-2008), Rapport GHAAPPE RA 08.06 et EDF R\&D H-P76-2008-04291-FR, 77 p.

Behrmann-Godel J. and Eckmann R., 2003. A preliminary study of the migration of silver European eel (Anguilla anguilla L.) in the River Mosel, Germany. Ecol. Freshwater Fish, 12, 1-7.

Boubée J. and Williams E.K., 2006. Downstream passage of silver eels at a small hydroelectric facility. Fish. Manage. Ecol., 13, 165-176.

Brown L.S., Haro A. and Castro-Santos T., 2009. Three-dimensional movements of silver-phase American eels in the forebay of a small hydroelectric facility. In: Casselman J.M. and Cairns D.K. (eds.), Eels at the edge: science, status and conservation concerns, American Fisheries Society Symposium, 58, Bethesda, 277-291.

Bruijs M.C.M., Polman H.J.G., Van Aersen G.H.F.M., Haddering R.H., Winter H.V., Deerenberg C., Jansen H.M., Schwewers U., Adam B., Dumont U. and Kessels N., 2003. Management of silver eel: human impact on downstream migrating eel in the river Meuse - Final Report, Contract Q5RS-2000$31141,106 \mathrm{p}$.

Carr J.W. and Whoriskey F.G., 2008. Migration of silver American eels past a hydroelectric dam and through a coastal zone. Fish. Manage. Ecol., 15, 393-400.

Chanseau M., Barrière O. and Travade F., 2002. Étude de la migration de dévalaison des juvéniles de saumon Atlantique (Salmo salar) au niveau des aménagements hydroélectriques de Castetarbe, Baigts-de-Béarn et Puyoo sur le Gave de Pau en 2001, Rapport EDF R\&D LNHE, HP-76/02/035/A, $34 \mathrm{p}$.

Durif C., 2003. La migration d'avalaison de l'anguille européenne (Anguilla anguilla). Caractérisation des fractions dévalantes, phénomène de migration et franchissement d'obstacles. Ph.D. Thesis, Université de Toulouse, $348 \mathrm{p}$.

Durif C., Gosset C., Rives J., Travade F. and Elie P., 2003. Behavioral study of downstream migrating eels by radio-telemetry at a small hydroelectric power plant. In: Dixon D.A. (ed.), Biology, Management, and Protection of Catadromous Eels, American Fisheries Society Symposium, 33, Bethesda, 343-356. 
EPRI, 2001. Review and documentation of research and technologies on passage and protection of downstream migrating catadromous eels at hydroelectric facilities, Report, Electric Power Research Institute (EPRI), Palo Alto, CA. 1000730, 73 p.

Gosset C. and Garaïcoechea C., 1974. Cuve galvanonarcotique pour la mensuration des poissons. Bull. Fr. Pêche. Piscic., 225, 72-76.

Gosset C. and Rives J., 2005. Anesthésie et procédures chirurgicales pour l'implantation de radio émetteurs dans la cavité ventrale de truites communes adultes (Salmo trutta). Bull. Fr. Pêche. Piscic., $374,21-34$.

Gosset C., Travade F., Durif C., Rives J. and Elie P., 2005. Tests of two types of bypasses for downstream migration of eels at a small hydroelectric plant. River Res. Applic., 21, 1095-1105.

Hadderingh R.H. and Baker H.D., 1998. Fish mortality due to passage through hydroelectric power stations on the Meuse and Vecht rivers. In: Jungwirth M., Schmutz S. and Weis S. (eds.), Fish Migration and Fish Bypasses, Fishing News Books, Oxford, 315-328.

Hadderingh R.H., Van Aerssen G.H., De Beijer R.F. and Van Der Velde G., 1999. Reaction of silver eels to artificial light sources and water currents: an experimental deflection study. Regul. Rivers Res. Manage., 15, 365-371.

Haro A., Castro-Santos T. and Boubée J., 2000. Behavior and passage of silver-phase American eels, Anguilla rostrata (Lesueur), at a small hydroelectric facility. Dana, 12, 41-50.

Hosmer D.W. and Lemeshow S., 2000. Applied Logistic Regression, John Wiley \& Sons, New York, $375 \mathrm{p}$.

Larinier M. and Travade F., 2002. Downstream Migration: Problems and Facilities. Bull. Fr. Pêche Piscic., 364 Suppl., $181-208$.

Monten E., 1985. Fish and turbines: fish injuries during passage through power station turbines, Stockholm, Sweden: Vattenfall, $111 \mathrm{p}$.

Pöhler F., 2006. Experience with eel friendly operation modus of hydropower plants. International DWA symposium on water resources management, Berlin, 3-7 April 2006.

Sand O., Enger P.S., Karlsen H.E., Knudsen F. and Kvernstuen T., 2000. Avoidance responses to infrasound in downstream migrating European silver eels, Anguilla anguilla. Environ. Biol. Fishes, 57, 327-336.

Tesch F.W., 1977. The eel - Biology and management of anguillid eels, London, Chapman Hall, 434 p.

Travade F. and Larinier M., 2006. French experience with downstream migration devices. International DWA symposium on water resources management, Berlin, 3-7 April 2006.

Watene E.M., Boubée J. and Haro A., 2003. Downstream movements of mature eels in a hydroelectric reservoir in New Zealand. In: Dixon D.A. (ed.), Biology, Management, and Protection of Catadromous Eels, American Fisheries Society Symposium, 33, Bethesda, 295-305. 